\title{
RBM4 Gene
}

National Cancer Institute

\section{Source}

National Cancer Institute. RBM4 Gene. NCI Thesaurus. Code C106255.

This gene plays a role in both alternative splicing and mRNA translation. 